\author{
Artur Golak \\ Uniwersytet w Białymstoku \\ ORCID 0000-0003-3854-150X \\ DOI https://doi.org/10.21697/ucs.2021.27.1.02
}

\title{
SPOŁECZEŃSTWO POLSKIE WOBEC ARMII ROSYJSKIEJ W PIERWSZYCH MIESIĄCACH I WOJNY ŚWIATOWEJ NA PODSTAWIE LITERATURY WSPOMNIENIOWEJ
}

\author{
Polish society attitudes towards the Russian Army in the first months of the Great War \\ on the basis of memorial literature
}

\begin{abstract}
Streszczenie
Celem niniejszego artykułu jest ukazanie wizerunku żołnierzy rosyjskich prezentowanego na kartach literatury wspomnieniowej, dokumentującej pierwszy rok Wielkiej Wojny. Tekst prezentuje postawy i opinie na temat żołnierzy armii rosyjskiej. Konfrontowane są one z ukształtowanym, skrajnie negatywnym, stereotypem rosyjskiego żołnierza funkcjonującym w polskim społeczeństwie. W artykule prezentowane są opinie indywidualne oraz spostrzeżenia wynikające z obserwacji reakcji ogółu mieszkańców, a dotyczące zachowania rosyjskiego wojska, relacji z cywilami, prezencji żołnierskiej. W artykule autor wskazuje na elementy rzeczywistości społeczno-politycznej, które były źródłem takiego stanu rzeczy.
\end{abstract}

Słowa kluczowe: I wojna światowa, Wielka Wojna, Królestwo Polskie, rosyjscy żołnierze, Kozacy, stereotyp

\begin{abstract}
The purpose of this article is to present the image of Russian soldiers as presented in the memoirs documenting the first year of the Great War. The text presents the attitudes and opinions expressed and presented about the soldiers of the Russian army. This is confronted with the formed, extremely negative stereotype of the Russian soldier functioning in Polish society. The text presents individual opinions and observations resulting from the scrutiny of the reactions of the general population, concerning the behavior of the Russian army, relations with civilians, and military presence. In the article, the author points to the elements of the socio-political reality that were the source of this state of affairs.
\end{abstract}

Key words: World War I, the Great War, the Kingdom of Poland (Congress Poland), Russian soldiers, Cossacks, stereotype

Rekonstrukcja nastrojów społecznych, nawet w okresie mniej burzliwym niż czas wojny, nie jest zadaniem prostym, a mimo to, lub właśnie z tego powodu, wielu historyków podejmuje badania tego typu zjawisk (Jaroniec 2016; Florczak 2018; Smoliński 2017). Kwestia odtwarzania nastawienia społeczeństwa wobec armii państwa zaborczego, a już szczególnie rosyjskiego, wydaje się zadaniem tym bardziej złożonym. Wiele klasycznych metod badawczych jest w takim wypadku bezużytecznych, zawodzą zwłaszcza te wywodzące się z dorobku nauk socjologicznych. Brak tu możliwości skonfrontowania badanego źródła z jego wytwórcą. Metody wypracowane przez historyków również nie są w pełni satysfakcjonujące. W oficjalnych źródłach urzędowych problem nastrojów społecznych jest słabo odzwierciedlony lub też zniekształcony przez oficjalną percepcję wydarzeń. W tym przypadku pomocny będzie, typowy dla warsztatu historyka, rodzaj źródła historycznego, wywodzący się z piśmiennictwa memuarystycznego, do którego można zastosować metodę badawczą wspólną warsztatowi socjologa i historyka - analizę treści dokumentu-źródła. 
Literatura wspomnieniowa w hierarchii źródeł poznania dziejów zajmuje szczególne miejsce, oferując historykowi równie wiele szans jak zagrożeń. Dla badacza dziejów to istotny materiał badawczy, w dodatku w przypadku historyka epoki nowożytnej występujący w imponującej, w porównaniu z wcześniejszymi okresami, ilości. Wiąże się to zarówno z upowszechnieniem edukacji, jak też ze wzrostem świadomości społecznej osób wytwarzających ten rodzaj źródeł. Warto mieć na uwadze, że o ile w epoce przednowożytnej umiejętność czytania i pisania dotyczyła w znacznej mierze elit, to pod koniec XIX i na początku XX stulecia świadectwa piśmiennictwa wspomnieniowego pozostawiają przedstawiciele praktycznie wszystkich grup społecznych. W omawianym okresie memuarystyką zajmują się nie tylko wykształcone społeczności mieszczańskie i dworskie, ale także ludzie wywodzący się ze środowisk robotniczych, a nawet chłopskich (Pamiętniki chłopów 1935; Pamiętniki chłopów serja 2 1936). Bogata baza źródłowa literatury memuarystycznej, zawierająca specyficzny, bo wymagający głębokiej krytyki wewnętrznej materiał, pozwala realnie myśleć o odtworzeniu nastrojów mieszkańców Królestwa Polskiego w pierwszym okresie Wielkiej Wojny, w tym także sposobów postrzegania żołnierzy armii rosyjskiej.

W ramach piśmiennictwa memuarystycznego wy różnia się szereg gatunków literackich, takich jak pamiętnik, dziennik, wspomnienia, autobiografia, życiorys, kronika rodzinna czy relacje świadka. Jak trafnie zauważa Z. Wojtkowiak, w polskim porządku ontologicznym nazwy te stosowane są naprzemiennie i zjawisko to nie dotyczy wyłącznie języka potocznego (Wojtkowiak 2003, s. 51). Czynnikiem łączącym wszystkie przytoczone wyżej gatunki literackie jest autor źródła, który jest równocześnie zarówno podmiotem, jak i przedmiotem relacji zawartej w dziele. Problemów nastręcza już dokładne określenie zakresu różnorodności gatunkowej tego rodzaju literatury. Zgodnie z definicją zawartą w Stowniku terminów literackich pamiętnik jest „relacją prozatorską o zdarzeniach, których autor był uczestnikiem bądź naocznym świadkiem” (Głowiński 1976, s. 289). Autor hasła, rozwijając je, pisze dalej: „Pamiętnik interesować może w trojakiej perspektywie: a) jako źródło wiedzy historycznej, przekaz wiadomości o zdarzeniach - w takim przypadku wiarygodność relacji jest przedmiotem dokonywanej przez historyka krytyki (...)" (Głowiński 1976, s. 289). Jest to o tyle warte zauważenia, że twórca hasła w pierwszym rzędzie wskazał na wartość pamiętnika - i szerzej - literatury wspomnieniowej, jako źródła wiedzy historycznej, równocześnie dostrzegając konieczność przeprowadzenia pogłębionej analizy krytycznej źródła. W tak skonstruowanej definicji zwraca uwagę jeden element. Twórca hasła stawia autora relacji w roli uczestnika bądź też naocznego świadka, nie ustosunkowując się do przypadku, kiedy to autor nie jest ani bezpośrednim uczestnikiem zdarzenia, ani też jego naocznym świadkiem. Nie uwzględnia okoliczności, gdy autor opisuje fakty i wydarzenia wyłącznie zasłyszane, uzyskane za pośrednictwem relacji innej osoby lub innego, niezależnego od autora źródła. O tyle jest to istotne, że nawet pobieżna analiza piśmiennictwa wspomnieniowego udowadnia, że jest to ważne, o ile nie zasadnicze źródło wiedzy autora. Nawet jeżeli dla przeciętnego czytelnika nie jest to element wpływający w decydujący sposób na ocenę dzieła literackiego, to dla historyka jest już kwestią podlegającą analizie krytycznej.

Autor, chcąc ukazać jak najszersze tło wydarzeń z lat 1914-1915, posiłkował się materiałem pamiętnikarskim pochodzącym od zróżnicowanego kręgu twórców, począwszy od środowisk ziemiańskich, poprzez przedstawicieli mieszczaństwa, polityków skupionych wokół opcji rosyjskiej, aż po działaczy niepodległościowych Królestwa Polskiego i monarchii habsburskiej.

Rozwiązania społeczno-polityczne koncesjonowanej autonomii kulturowej i samorządowej Galicji niewątpliwie budziły uznanie społeczeństwa Królestwa Polskiego jako rzeczywista namiastka własnej państwowości, stąd, i tu dodajmy - mocno na wyrost - posądzanie Polaków i Żydów przez administrację rosyjską o nastroje proaustriackie. „Dwie »orjentacje« polityczne ujawniły się teraz (po wybuchu wojny z Niemcami - przyp. aut.). Wszyscy byliśmy radzi widzieć armię rosyjską bitą, a czynowników rosyjskich w ucieczce, lecz jedni uważając, że zwycięstwo germanizmu byłoby ostateczną zgubą Polski, pragnęli rozgromienia Niemiec, drudzy zaś liczyli, że Niemcy pójdą na Francję, Królestwo zaś zajmie Austrja, co dla Polski byłoby najpomyślniejsze (...)" - pisał ziemianin i działacz społeczny Jan Glinka (Glinka 1927, s. 12). Z drugiej strony bardzo trzeźwo oceniano austriacką ofertę wystosowaną do środowisk proaustriackich Królestwa Polskiego. „Nikt nie oczekiwał »manifestacyj« ani »za« Austrją, ani »przeciw» niej (autor nawiązuje tu do manifestacji przed ambasadą serbską z dnia 30 lipca - przyp. aut.). Czuć było, że nie ma nigdzie materjałów wybuchowych po temu. Od pamiętnego wystrychnięcia przez Austrię na dudka polskiej ufności w szczerość rakuskich oświadczeń 
i zamiarów upłynęło sporo zimnej wody..." (Jankowski 1923, s. 14). Jeszcze w roku 1908 gen. Aleksiej A. Brusiłow, nowo mianowany dowódca XIV korpusu, pisał w pamiętnikach, że znalazł się wśród ludności polskiej w większości Rosji i Rosjanom wrogiej (Dobroński 1976, s. 257).

Jak konstatuje A. Achmatowicz, społeczeństwo Królestwa Polskiego nie przyjmowało do wiadomości, że po śmierci arcyksięcia Franciszka Ferdynanda Habsburga nastąpiła eskalacja sytuacji politycznej w Europie (Achmatowicz 2003, s. 170). Od ponad dwóch dekad napięcie w Europie rosło, po czym dochodziło do normalizacji stosunków między mocarstwami. Tak i teraz spodziewano się raczej nowego paneuropejskiego kongresu pokojowego, który na drodze dyplomatycznej rozwiąże konflikt serbsko-habsburski (Chwalba 2014, s. 24-25). W stolicy Królestwa Polskiego na wybuch wojny na Bałkanach zareagowała tylko diaspora rosyjska, demonstrując 30 lipca, w porozumieniu z magistratem, solidarność z narodem serbskim, przy czym manifestacja odbywała się z wypożyczonym z pałacu prezydenta-szambelana Aleksandra A. Millera portretem Mikołaja II („Kurier Warszawski” 1914, nr 209, s. 4). Znaczącym był za to fakt masowych wyjazdów urzędników rosyjskich razem z rodzinami, i to pomimo uspokajającego wezwania do powrotu na swe stanowisko wystosowanego przez warszawskiego generał-gubernatora gen. Jakowa G. Żylińskiego 25 VII 1914 r. Quasiucieczka nie była spowodowana obawą o wybuch wojny - w takim przypadku Królestwo Polskie stałoby się bezpośrednią strefą przyfrontową - chodziło bardziej o polską irredentę, połączoną z pogromami Rosjan.

Jak pisał Stanisław Dębiński, członek nielegalnej niepodległościowej organizacji Konfederacji Narodu, stan rozprężenia administracji trwał 10 dni, po czym sytuacja została opanowana, a znaczna część urzędników powróciła na miejsce pełnienia służby (Achmatowicz 2003, s. 172-175).

Sytuacja zmieniła się radykalnie po ogłoszeniu częściowej mobilizacji 16 lipca 13 korpusów, terytorialnie obejmujących obszary przygraniczne z Austro-Węgrami, a następnie mobilizacji pełnej ogłoszonej dwa dni później przez Mikołaja II. Na sam wybuch wojny zareagowała prasa codzienna, m.in. drukując i kolportując liczne dodatki nadzwyczajne, wychodzące w odstępie nawet kilku godzin, informując na bieżąco o zmieniającej się sytuacji międzynarodowej („Kurier Warszawski” 1914, nr 211, dodatek nadzwyczajny, „Kurier Warszawski" 1914, nr 211 2-gi dodatek nadzwyczajny).

Do tej chwili społeczeństwo polskie miało zachowywać daleko posuniętą rezerwę i ostrożność wobec maszerujących oddziałów rosyjskich, a prasa codzienna używać bardzo ogólnych określeń, nie wychodząc poza kanon cenzorski (Achmatowicz 2003, s. 195-196). Tymczasem ks. Lubomirska w swoim dzienniku, we wpisie z dnia 4 sierpnia (można więc domniemywać, że opisywany fakt miał miejsce wcześniej), pisze: „Wieczorem szły pod naszymi oknami liczne oddziały wojska, długim korowodem. Towarzyszył im tłum entuzjastyczny, krzycząc hurra!!! Niech żyje armia! Cała ulica drżała zapałem. Wstrząsający był to widok w tę noc gwiaździstą - widok nowy, nieoczekiwany. Gdzież mary przeszłości. Czyż Kościuszkę dreszcz w grobie nie przeszywa? Co by powiedział mój Teść, gdyby mógł wśród nas się odnaleźć. Myślałam dziś długo o księciu Tadeuszu. Kędyż by sterował Jego potężny patriotyzm” (Lubomirska 2002, s. 15). Analizując tę część źródła, należy zwrócić uwagę na datę jego powstania. Część badaczy stoi na stanowisku, że gwałtowny, wręcz euforyczny wybuch nastrojów prorosyjskich wynikał z informacji o ostrzale artyleryjskim Kalisza. Zdarzenie to miało miejsce w godzinach popołudniowych 4 sierpnia. Trudno też podejrzewać pedantyczną autorkę, by ten fakt całkowicie pominęła. Tak więc należy uznać, że entuzjastyczna reakcja mieszkańców Warszawy nie była wynikiem wiadomości z Kalisza, a już na pewno nie nastąpiła wskutek wypowiedzenia przez monarchię habsburską wojny Rosji.

Podobne opisy towarzyszą też innym relacjom. Czesław Jankowski tak opisuje pierwsze dni wojny w Warszawie: „W ciągu 2-3 tygodni mieliśmy nieustanne przeciąganie przez Warszawę niezliczone ilości wojska. Prawie wyłącznie piechoty (strzelcy) i artylerii. (...) Publiczność tworzyła po chodnikach istne szpalery, nie tylko przyglądając się armii autentycznie bojowej, ale i nieszczędząc objawów sympatii dla defilującego wojska. Rezerwistów warszawskich gdy po ich wyekwipowaniu na polu wyścigowem, wyciągali z miasta - podobno w kierunku Modlina - publiczność żegnała wręcz owacyjnie, wznosząc okrzyki, powiewając chustkami. Mnóstwo osób rozdawało wymaszerowującym na plac boju żołnierzom: papierosy, upominki, żywność, szkaplerze, medaliki” (Jankowski 1923, s. 21).

Część badaczy usiłuje tłumaczyć deklaracje sympatii dla rosyjskiego wojska dużą liczbą polskich rezerwistów, choć badania prowadzone przez A. Dobrońskiego w znacznej mierze przeczą tej tezie. W okresie po 
rewolucji 1905 r. odsetek powoływanych poborowych zmniejszał się, a w guberniach Królestwa Polskiego obowiązywały wyższe limity poboru, które miały zrekompensować nieproporcjonalnie wysoki wskaźnik zwolnień i odroczeń (Dobroński 1979, s. 246). Czesław Jankowski relacjonuje dalej: „Temiż względami cieszyły się wojska czysto rosyjskie, przybyłe z Saratowa, i Kazania, a przeciągające przez Warszawę. Panie nasze z równą życzliwą i serdeczną intencją, jak »swoim«, rozdawały np. medaliki katolickie - prawosławnym. Ci je chętnie brali i dziękowali, widocznie ukontentowani” (Jankowski 1923, s. 22). Ciekawym spostrzeżeniem autora, prezentującym relacje z rosyjskim wojskiem nie tylko w kontekście narodowym, ale i religijnym, jest kolejny passus pamiętnika. „Znaczne oddziały piechoty tłoczą się na statku przystani na Wiśle, aby odpłynąć gdzieś w górę rzeki. Przybywa oddział spory, któremu towarzyszył ksiądz w komży. Gdy się oddział uszykował u pomostu wiodącego na statek, ksiądz podnosi głos uroczyście. - Kto katolik, niech uklęknie. Pobłogosławię! A z szeregów odzywa się ktoś po rosyjsku. - Jeden Pan Bóg dla wszystkich! I cały oddział pada na kolana. Ksiądz kreśli nad klęczącymi znak krzyża - i łzy mu płyną po twarzy" (Jankowski 1923, s. 22). Nawet zakładając, że anegdota jest beletryzowana, to pozwala lepiej zrozumieć nastrój pierwszych tygodni wojny, przełamujący również stereotypy wyznaniowe.

Można by domniemywać, że powyższe opisy, których autorami byli zdecydowani przeciwnicy opcji niemieckiej, stanowiły zniekształcone poglądy polityczne i wskazywały na rosnącą germanofobię. Bliźniaczo podobne spostrzeżenia artykułują również obserwatorzy niekryjący dezaprobaty dla takiego stanu rzeczy. Tadeusz Hołówko, współtwórca Polskiej Organizacji Wojskowej (POW), tak pisze: „I oto zobaczyliśmy obraz, którego nie zapomnę do końca życia. Nowym Światem ciągnął pułk kozaków z orkiestrą na czele i szedł ten pułk otoczony tłumem rozentuzjazmowanej polskiej publiczności, która krzyczała: „Niech żyje nasze wojsko”, „Niech żyją nasi obrońcy”. Panie, rozgorączkowane, z błyszczącymi oczyma szybko kupowały kwiaty i biegły w środek szeregów końskich, aby wręczyć je oficerom, panowie opróżniali swe papierośnice i wtykali papierosy kozakom, którzy z wysoka, z pobłażliwym uśmiechem przyjmowali te oznaki zachwytu. Jakby kto sztylet wsadził mi w serce" (Hołówko 1924, s. 21). Bardzo krótko konstatuje ten stan rzeczy Ignacy Daszyński: "Jeżeli co było w historii i wyobraźni polskiej wrogim i nienawistnym, to kozacy" (Daszyński 1957, s. 190).

Jednostki kozackie i stosunek do nich polskiego społeczeństwa stanowią ważny element dyskursu pamiętnikarskiego. Nawet wśród pamiętnikarzy pozytywnie lub choćby neutralnie relacjonujących reakcje mieszkańców Królestwa Polskiego na armię rosyjską, demonstrowanie sympatii wobec Kozaków budzi pewien dysonans poznawczy. Często twórcy źródeł odnoszą się do wypadków rewolucji 1905 roku i udziału formacji kozackich w ich tłumieniu. Ponownie Czesław Jankowski: „Kozaków nie widzieliśmy dotąd wcale na ulicach Warszawy. Jeżeli droga ich prowadziła przez gród Syreni, to chyba - nocą. Prawda! Któregoś dnia jechał Marszałkowską nieduży oddział Kozaków. Przechodnie podnosili głowy, każdy rzucał okiem - ale nikt na chodniku nie przystanął. Kozacy! Dobry, zacny ludku warszawski! W porywie orientacji politycznej, podyktowanej ci żywiołowo przez najzdrowszy rozsądek, lub odruchowo na wieść o barbarjach pruskich, bodaj-że, po raz pierwszy od czasów Aleksandra I-go Błogosławionego (lub Le Bien Aime) - tyś powiewał chustkami, wiwatował i machał kapeluszami manifestując gorąco i szczerze sympatie swoje dla... wojska rosyjskiego. Ale czy ty, Warszawo, byłabyś zdolna obsypać kwiatami - kozaków" (Jankowski 1923, s. 23). W tym miejscu nawet autor relacji czuje się w obowiązku umieścić przypis do informacji prasowej z 27 sierpnia, opublikowanej w „Kronice Piotrkowskiej”: „W dniu 27 sierpnia podała »Kronika Piotrkowska« następującą wiadomość: »Po ustąpieniu niemców dziś o g. 8-ej rano wjechał do naszego miasta od strony Łodzi pierwszy podjazd rosyjski, złożony z pięciu kozaków dońskich i objeżdżał ulice miasta. Na rynku obdarzono kozaków kwiatami. O g 9 i pół wjechała do miasta secina kozaków dońskich, którą przyjmowano z całą sympatią i również na rynku obdarzono kwiatami«" (Jankowski 1923, s. 23).

Gwałtowna zmiana w ocenie wojsk rosyjskich, w tym pułków kozackich, stanowi poważny dysonans nawet dla formułujących opinie o charakterze osobistym. Księżna Lubomirska zapisała w dniu 15 września: „Zasępione nasze czoła rozchmurzyła dziś wieczór wiadomość ze stacji kolejowej, że stłukli Niemców pod Suwałkami, topiąc opornych w tamtejszych jeziorach. Wściekły, radosny taniec wokoło stołu przed obiadem. 
Czy tylko prawda?... Cóż za upojenie w samym echu zwycięstwa; jeśli tak dla cywilów, cóż dopiero dla żołnierzy? Teraz, jak mówi Mama, les cosaques sont devenus nos anges gardiens”' (Lubomirska 2002, s. 53).

Bliski kontakt pozwolił stworzyć zupełnie nowe, wręcz intymne relacje. W anegdotycznym opisie autorki pobrzmiewa wspomnienie czasów, kiedy to dworscy Kozacy stanowili integralną część rzeczywistości ziemiańskiej. We wpisie z dnia 24 września pisze: „Przeżyli istną epopeję: mieli w domu kozaków (...). Kozacy znosili im łupy i pomagali Natalce [w] trzepaniu dywanów i w wyrobie masła” (Lubomirska 2002, s. 59). Humorystycznie w kontekście relacji miejscowych kobiet z wojskiem brzmi wpis ks. Lubomirskiej z dnia 28 maja 1915 roku: „Wycieczka do Małejwsi - długa wizyta u księdza (...). „Nareszcie - rzecze do mnie z westchnieniem zacny proboszcz - poznałem kobietę polską! Za cukierek, za suknię, gotowa do wszystkiego - straszna demoralizacja!« - „Czy żołnierze dopuszczają się gwałtów?« - pytam niespokojnie. - Bynajmniej, nie ma takiej potrzeby. Widuję dobrowolne, wieczorne schadzki, przestrzegam z ambony, ale jest to głos wołającego na puszczy. Piechurom pospolitym zdolne się oprzeć - ale gdy zjawi się kozak z brodą, przyniesie lada podarek, a obieca ślub po wojnie, wnet mu ulega białogłowa" (Lubomirska 2002, s. 185).

Niezwykle ciekawe, zwłaszcza w kontekście skrajnie negatywnego, ocierającego się o szowinizm, stereotypowego wizerunku Rosjanina Azjaty, są występujące w źródłach opisy powierzchowności rosyjskich żołnierzy. Znaczący wydaje się być opis przemarszu jednostek gwardyjskich pióra ks. Lubomirskiej. Wpis z 15 sierpnia: „...) Wieczorem znów szła nieliczna (niezliczona) ilość wojska Krakowskim Przedmieściem, tym razem lejbgwardia petersburska i pawłowskie pułki. Przepyszni żołnierze, rośli, o jasnych twarzach, o zgrabnym, falistym kroku. Oficerowie mniej zdrowo wyglądali, znać już na innym polu laury zbierali. (...) Idą... idą... porządkiem” (Lubomirska 2002, s. 24). W dalszej części pamiętnika pochwały kierowane są nie tylko w stronę jednostek elitarnych. Wpis z dnia 6 października: „(...) ze strony Rosji ciągną najdzielniejsze mołojce, idą wspaniałe pułki litewskie, syberyjskie” (Lubomirska 2002, s. 62). Nie oznacza to, że siatka pojęciowa, która ukształtowała stereotypowy wizerunek rosyjskiego żołnierza, przestała istnieć. Jest nadal zauważalna, choć pozbawiona negatywnych czy szowinistycznych konotacji. Wpis ks. Lubomirskiej z dnia 3 października: „Od paru dni przez Warszawę ciągną jakieś zbrojne plemiona azjatyckie - koniki mają małe, długowłose - o nieznanym obyczaju” (Lubomirska 2002, s. 60). W źródłach występują opisy konkretnych osób, z którymi pamiętnikarze mają bezpośredni kontakt: „Przechodzili u nas Kozacy Kubańscy, t.zw. Czerkiesi konsystujący stale w Warszawie. Śliczni ludzie i prawdziwi rycerze. Esauł jeden pokazywał nam szablę starożytną, po przodkach odziedziczoną" (Glinka 1927, s. 18).

Pozytywne wrażenie Kozacy pozostawiają po sobie w środowisku wiejskim, chociaż istniało szerokie pole do licznych zadrażnień z miejscową ludnością, o czym zaświadcza wpis hr. Ostrowskiej z dnia 6 września: „(...) Od tego czasu co kilka dni przejeżdżały tędy patrole kozackie po 20, po 30 koni lub Czerkiesów kubańskich, nie budząc w ludności postrachu, gdyż zachowywali się przyjaźnie i zupełnie poprawnie, płacąc za wiktuały i owies" (Ostrowska 2014, s. 70). Poprawny stosunek do własności ludności miejscowej wynikał w znacznej mierze z własnego zaopatrzenia; w przypadku braków wojsko sięgało po sprawdzony sposób rekwizycje, choć i na ten temat brak opisów przemocy czy przymusu. Hrabina Ostrowska dokumentuje chwilę wyparcia wojsk niemieckich z okolic rodowej siedziby - Maluszyna: „Przybywa coraz to więcej kozaków i także piechoty (...). Napełnia się okolica wojskami rosyjskimi zgłodniałymi. Zwycięzcy o wiele biedniej idą jak zwyciężeni, maleńki tabor z podwodami. Zapasów nie mają - tym trudniej ich wyżywić po poprzednim objedzeniu - biwakują na polu, zabijają nam krowy, kupują mąkę, zwożą drewno z lasu, łamią płoty i pieką chleb na sodzie w domach; nasza czeladnia izba napchana, płaczą kobiety niewyspane i zmordowane, ale stosunek prędzej przyjazny i żadnych gwałtów” (Ostrowska 2014, s. 83-86). Wpis z 14 listopada brzmi podobnie, wskazując na wciąż wysokie morale rosyjskich żołnierzy i ich stosunek zarówno do warunków życia ludności miejscowej, jak i uciążliwości, jaką niesie ze sobą obecność wojska: „Na noc przyjeżdża inny jenerał z kilkunastu oficerami - to sąd wojenny. Gościnę przyjmuje, ale odmawia wszelkiego żywienia, mówiąc, że oni mają, a tu ludzie i tak ogołoceni ze wszystkiego. Nawet bułki nie chce przyjąć, tylko kupuje" (Ostrowska 2014, s. 93).

$1 \quad$ Kozacy stali się naszymi aniołami stróżami. 
Nie brakuje opisów zjawiska stereotypowo utożsamianego z armią rosyjską - powszechnie występującej korupcji, choć sam autor relacji jednoznacznie oskarża o składanie propozycji łapówkarskich zawodowych oficerów, z którymi miał styczność w pierwszym okresie wojny: „Jeden z żołnierzy raz do mnie o kupno owsa. Powiedziałem mu cenę i oznajmiłem, że rachunków fałszywych nikomu nie piszę, ale furażerom daję stale 2 kop. od puda z własnej kieszeni, tak bowiem urządziłem się ostatecznie, aby uniknąć, przynajmniej z żołnierzami, targów o pokwitowania. Kozak z początku nie wiedział o co chodzi, gdy zrozumiał, zaczerwienił się i zawołał: „Jak to, jakbym miał gonić za nieuczciwym zarobkiem? Gdy idę na śmierć, będę myślał o pieniądzach! Przekląłby mnie mój ojciec i dziad” (Glinka 1927, s. 18). I relacja tego samego autora, już po zażegnaniu kryzysu zaopatrzeniowego pierwszych tygodni wojny: „Zaopatrzenie armii kolejami było wówczas znakomite, żywności i furażu miało wojsko w bród, owsa ani siana od nas nie kupowało, nie było już więc okazji do dyskusji nad fikcyjnymi cenami, i to nasze stosunki z oficerami pozwalało utrzymać na stopie towarzyskiej, dobrego wychowania i wzajemnej uprzejmości. Nieraz zastanawialiśmy się, nad tem, czy ci sami dżentelmeni, gdyby coś kupowali, proponowaliby, jak przed półrokiem ich koledzy, fałszowanie pokwitowań" (Glinka 1927, s. 37).

Interesującym aspektem, zauważalnym zwłaszcza na wsi, było postrzeganie rosyjskich żołnierzy jako namacalnego dowodu na ciągłość istnienia władzy carskiej. W wielu relacjach pobrzmiewa echo antagonizmów na linii dwór - wieś oraz wizja rosyjskiego cara jako gwaranta praw wynikających z uwłaszczenia włościan. Ksiądz Józef Rokoszny w Diariuszu Wielkiej Wojny pisał: „(...) Spotkałem pana Darowskiego z Koprzywnicy. Opowiadał, że skoro pojawiły się u nich straże kozackie i ułańskie, chłopi i baby po wsiach witały ich serdecznie, całowały po rękach. Chłopi wnieśli kilku kozaków na rękach (...). Po obiedzie przyjechał ksiądz Zajączkowski z księdzem Gierowskim z Sulisławic i opowiadali, co tutaj działo, jak kobiety klękały przed patrolem rosyjskim, jak kozakom wygadywały niestworzone rzeczy na księży” (Przeniosło 1990, s. 171). Jeszcze bardziej kategorycznie brzmi to w relacji Juliusza Jamroza, emisariusza legionowego, prowadzącego działalność werbunkową na terenach opuszczonych przez wojska rosyjskie. W swoim raporcie pisze: „Pomimo wszystko udało mi się skonstatować, że ludność miejscowa, tj. inteligencja i mieszczaństwo, przyjmuje nas z otwartymi rękami, sprzyja naszym dążeniom, ale chłopstwo usposobione do nas złowrogo i okazuje pewne niezadowolenie widząc nas wkraczających w ich życie codzienne. Oto obrazek, który powinien oświetlić wyżej wspomniane: Kiedyś udało mi się zwołać zebranko we wsi Cierno i Suchodole i po przemówieniu do nich i tłumaczeniu usłyszałem li tylko tyle: "my ludzie cesarscy, nasz car przyjdzie na Wielkanoc, da nam zboża, będzie dzielił się z nami jajkiem a nie tacy i owacy 'Austriacy'", po zabraniu głosu i tłumaczeniu, że tak nie będzie, obrzucono i mnie epitetami” (Przeniosło, 1990, s. 170).

Odnotowywano liczne wypadki, kiedy to po wyparciu wojsk niemiecko-austriackich chłopi denuncjowali wojsko rosyjskim osoby sympatyzujące z legionistami. Równie gwałtowna reakcja chłopów towarzyszyła pogłoskom o przymusowym poborze do legionowego wojska, co wiązało się z masowymi ucieczkami wiejskiej młodzieży z miejsca pobytu (Przeniosło 1990, s. 171-179).

Stawiając tezę o przychylnej atmosferze panującej wokół rosyjskich żołnierzy, można zastanawiać się zarówno nad przyczyną takiego stanu rzeczy, jak i nad autentyzmem reakcji ludności polskiej. Każdym zjawiskiem społecznym można sterować, toteż istotne jest przyjrzenie się narzędziom służącym kształtowaniu opinii społecznej. Z przytoczonych źródeł wynika, że prasa warszawska wypowiadała się o panującej sytuacji nader oszczędnie, zajmując pozycję wyczekującą. Pozytywny stosunek do obowiązku powszechnej mobilizacji nie może być traktowany jako rozstrzygający dowód na pozytywny stosunek ludności polskiej do rosyjskiego wojska, ponieważ wiele czynników mogło decydować o chęci włożenia rosyjskiego munduru. Począwszy od obowiązku patriotycznego i chęci osobistego uczestnictwa w obronie granic Królestwa Polskiego przed spodziewaną agresją państw centralnych (gdzie barwa munduru był sprawą drugorzędną), poprzez swoiście pojmowaną lojalność dla domu panującego - rezerwiści składali przysięgę na wierność carowi, skończywszy na zwykłej obawie przed represjami wynikającymi z niestawiennictwa przed odpowiednimi organami. Środowiska konserwatywne mogły obawiać się rewolucji socjalistycznej, która miała być następstwem zwycięstwa myśli politycznej lewicowych działaczy skupionych w Najwyższym Komitecie Narodowym. Ignacy Daszyński pisał po zajęciu Warszawy latem 1915 roku: „Klasy bogatsze oczekiwały powrotu „taty” - wojska rosyjskiego (...). Rusofile, mający w Warszawie większość tzw. „opinii”, czekali zwycięstwa rosyjskiego i nie 
ustosunkowali się wcale do zwycięstwa niemieckich, a tym mniej myśleli o zbliżeniu do ruchu legionowego" (Daszyński 1957, s. 217-218). Z pewnością należy wnikliwie przeanalizować motywację najliczniejszej grupy społecznej Królestwa Polskiego - chłopów. O stopniu polaryzacji między dworem a mieszkańcami wsi świadczyły pojawiające się, nawet w swoim wyrazie absurdalne, zarzuty wobec szlachty o handel chłopami (Przeniosło 1999, s. 171).

Inaczej trzeba ocenić skalę ochotniczego zaciągu w szeregi armii. Należy zgodzić się, że ta była znaczna, tym bardziej że przed wojną istniały szacunki, że do $20 \%$ rezerwistów może nie stawić się do służby (Legieć 2013, s. 275). Część obserwatorów usiłowała tłumaczyć to zgłaszaniem się młodych Rosjan mieszkających w Królestwie Polskim. Według informacji prasowych do 8 sierpnia stawiło się w Warszawie 500 ochotników. Do 10 sierpnia po niezbędny dla zaciągu dokument świadectwa lojalności zgłosiło się ok. 1000 mężczyzn. Jak konstatuje A. Achmatowicz, już ta liczba przekraczała możliwości demograficzne rosyjskiej diaspory. Tymczasem do 14 sierpnia chęć przywdziania rosyjskiego munduru deklarowało ok. 1700 ochotników (według innych danych blisko 3000). Według prasowych enuncjacji większość z nich wywodziła się z kręgów młodzieży rzemieślniczej, co wyłącza raczej Rosjan (Achmatowicz 2003, s. 205-206).

O ochotniczym zaciągu etnicznych Polaków do wojska wspomina, nie ukrywająca sceptycyzmu, a nawet wrogości wobec Rosjan, Janina Gajewska: „Fakt, że u nas w Warszawie wstępuje do wojska rosyjskiego mnóstwo ochotników Polaków, jest chyba najwymowniejszy. W tym samym duchu przemawiali także posłowie polscy w Dumie, powiedziałbym nawet, że zbyt uprzejmie" (Gajewska 2014, s. 42). O zaciągu polskiej młodzieży, i to z kręgów arystokratycznych, wspomina także ks. Lubomirska we wpisie z 15 sierpnia: „Po południu odwiedził mnie Stefan Lubomirski. Syn jego Tomek, idzie na ochotnika do pułku preobrażeńskiego; Stefan dumny i trwożny - boi się wracać do domu, bo może i Hieronim popędzi za bratem, a zanim do wojska ucieknie i Władek, a wtedy, kto wie, czy zapalona Natalka munduru nie przywdzieje!” (Lubomirska 2002, s. 24).

O rzeczywistych nastrojach społecznych towarzyszących wybuchowi wojny może świadczyć także reakcja czynników oficjalnych. Sprawność, z jaką w Królestwie Polskim odbyła się mobilizacja, została dostrzeżona w Petersburgu. W dniu 7 sierpnia, w czasie uroczystego bankietu dla osobistości życia publicznego rosyjskiego imperium, z udziałem 250 notabli, obecni byli m.in. P. Struve, A. Brianczaninow oraz prof. W. Wiedenski. Jak odnotowuje A. Achmatowicz, deklarowany podczas oficjalnych wystąpień stosunek do Polaków był co najmniej ciepły. Czesław Karpiński, działacz Stronnictwa Narodowo-Demokratycznego i członek Rady Państwa, podkreślił, że „(...) w Polsce wszędzie panuje duch lojalności. Mobilizacja przebiega bez zakłóceń (...)” (Achmatowicz 2003, s. 234). Wyrazy sympatii wobec Polski i Polaków padały nawet ze strony dotąd tradycyjnie antypolskich środowisk. Syn Jana Harusewicza, lidera Koła Polskiego w Dumie, przytacza anegdotę, według której jego ojciec został serdecznie wyściskany przez nieformalnego przywódcę skrajnych nacjonalistów, posła Władimira M. Puryszkiewicza, znanego dotąd jako zdeklarowany „polakożerca" (Achmatowicz 2003, s. 237).

Rezultat mobilizacji odnotowano także za granicą. W korespondencji dyplomatycznej państw sojuszniczych - Anglii i Francji, podkreślano atmosferę spokoju panującą w trakcie mobilizacji. O ile informacje o jej przebiegu w przypadku ambasady francuskiej pochodziły ze strony rosyjskiego ministra spraw wewnętrznych, to nota przesłana do Foreign Office opierała się na sprawozdaniu brytyjskiego wicekonsula w Warszawie, Edmunda Bower Saint Claira, który odnotował: „(...) w toku obecnej mobilizacji Polacy rosyjscy zachowali przychylną wobec Rosji postawę" (Achmatowicz 2003. s. 192). W prasie warszawskiej 8 sierpnia opublikowane zostało podziękowanie ze strony dowódcy 2 Armii gen. kawalerii Aleksandra W. Samsonowa. Fakt ten odnotowała ponownie ks. Lubomirska: „Dziś w gazetach było słowo podzięki i uznania od generała jazdy Samsonowa dla ludności polskiej z powodu ładu i spokoju, z jakimi odbyła się mobilizacja. Tak mało jesteśmy przyzwyczajeni do objawów życzliwości, że ta skromna odezwa nie minęła bez wrażenia" (Lubomirska 2002, s. 19). Podziękowanie rozpowszechniano także na plakatach miejskich. Część badaczy uznaje, że postawa społeczeństwa polskiego wynikała z obietnic politycznych zawartych w odezwie wielkiego księcia Mikołaja Mikołajewicza z 14 sierpnia 1914 r., choć ze źródeł pamiętnikarskich wynika, że oferta została przyjęta z dużą ostrożnością. 
Na pewno wpływ na polityczne wybory Polaków miała rosnąca germanofobia, obecna w dyskursie społecznym, zwłaszcza po zburzeniu Kalisza, czy w pogłoskach o zachowaniu jednostek niemieckich w zdobytej Częstochowie (Glinka 1927, s. 13). Opowiedzenie się po stronie antyniemieckiej mogło też wynikać z silnej pozycji Narodowej Demokracji, która ostatecznie przyjęła pozycję prorosyjską. Nie można również zapominać, że ludność Królestwa Polskiego podlegała analogicznym procesom jak ludność polska zamieszkująca obszary obejmujące zabory austriacki i pruski. Asymilacja państwowa ludności polskiej w państwie habsburskim i niemieckim była może nawet bardziej zaawansowana niż w Kongresówce. Tam również obserwowano demonstrowaną lojalność wobec „swoich” ojczyzn i „swoich” monarchów. Jan Szuścik, działacz polonijny ze Śląska Cieszyńskiego, relacjonował po latach: „,...) dużo ludzi cieszyło się z tego, że pójdą na Moskala. Przyznam się, że i ja się z tego cieszyłem. Mówiono ogólnie, że wojna skończy się za sześć tygodni, a najpóźniej za trzy miesiące" (Szuścik 1925, s. 8). Aleksander Lednicki, członek Centralnego Komitetu Obywatelskiego oraz Polskiego Towarzystwa Pomocy Ofiarom Wojny, przytacza we wspomnieniach rozmowy z niemieckimi oficerami pochodzenia polskiego w rosyjskiej niewoli: „,...) do naszej rozmowy przyłączyli się inni jeńcy, nawet nie tylko Polacy, i wywiązała się ożywiona dyskusja. Wkrótce został wprowadzony hr. Janusz Czarnecki, lejtnant armii niemieckiej, wysoki dwudziestoletni młodzieniec, sztywny, nie był łatwy w obcowaniu. Rozmowa nie kleiła się. Podział na kategorie państwowe był widoczniejszy" (Lednicki 1994, s. 28). I opis innej rozmowy: „(...) Zapytałem głośno po polsku: „Gdzie są tu Polacy?» Odpowiedzi nie otrzymałem. Ponowiłem pytanie po niemiecku, i któryś z oficerów bliżej stojących odpowiedział wskazując na łóżko w głębi sali, na którym leżał rosły mężczyzna o rudej brodzie i trzymał w ręku książkę: "Das istein Pole, Graf Koziebrodzki”. Zbliżyłem się do niego, witam po polsku i mówię: »Panie majorze, przychodzę do Pana w imieniu rodaków z pozdrowieniem i zapytaniem, czy nie potrzebuje Pan czego?« Musiałem dwukrotnie powtórzyć pytanie - milczał wreszcie przemówił: »Od Moskali niczego nie potrzebuję i niczego nie przyjmuję. Jego Cesarska i Królewska Mość Najmiłościwiej mnie panujący Pan, na czele swoich walecznych wojsk rozpędzi to moskiewskie bydło, które ma być wojskiem. Zrobi należyty porządek i ja, Bóg da, wrócę prędko do domu. Dziękuję Panu»" (Lednicki 1994, s. 33). Wydaje się, że lojalność wobec domów Habsburgów i Hohenzollernów ze strony Polaków służących w armiach austro-węgierskiej i niemieckiej miała podobne źródła jak nastawienie Polaków do Romanowów. Chęć obrony rodzinnych stron - Galicja i Wielkopolska byłyby naturalnymi celami domniemanej ofensywy rosyjskiej armii, czy utożsamianie Rosji z odwiecznym wrogiem Polski i polskości, w końcu obowiązek wierności panującym. Po roku 1916 liczni polscy poddani Franciszka Józefa i Wilhelma II Hohenzollerna myśleli o odzyskaniu niepodległości i walce z Rosją; oczywiście niepodległości w ramach wyznaczonych przez państwa zaborcze.

Klęski armii rosyjskiej z roku 1915 i pierwszej połowy 1916 wpłynęły w znaczny sposób na postrzeganie Imperium Rosyjskiego. Zwłaszcza odwrót z Królestwa Polskiego, połączony z taktyką spalonej ziemi, wpłynął na stosunek do Rosji i rosyjskich żołnierzy. Mit potężnego państwa i niepokonanej armii, który podtrzymywał lojalność wielu reprezentantów opcji prorosyjskiej, rozpadał się niemal na oczach polskiego społeczeństwa. Przełomem była rewolucja burżuazyjna, a następnie bolszewicka w Rosji i abdykacja cara. To ugruntowało zmianę poglądów ziemian, konserwatystów i chłopów. Rewolucja bolszewicka odcięła możliwość jakiejkolwiek formy współistnienia Polski i Rosji w jednym organizmie państwowym.

Stereotypy etniczne są istotnym elementem świadomości zbiorowej. W przypadku narodu pozbawionego własnej państwowości grały tym bardziej istotną rolę, ponieważ pozwalały nakreślić sylwetki obywateli państw zaborczych w sposób wyraźny i jasno określić relacje „my - oni”. W 2. połowie XIX w., w okresie formowania nowoczesnych narodów, pozwoliły wykazywać abstrakcyjne różnice między „„woimi” a „obcymi”, umacniać więzi wewnątrzspołeczne i niwelować różnice w obrębie własnej grupy.

Równocześnie brak oparcia w niezawisłym państwie wymuszał kształtowanie bytu narodu w bliskich relacjach z państwami zaborczymi. Reorientacja większości znaczących ośrodków opiniotwórczych Królestwa Polskiego w stronę państwa rosyjskiego w pierwszym okresie wojny zaowocowała krótkim, ale bardzo intensywnym wybuchem nastrojów prorosyjskich w polskim społeczeństwie. To zaowocowało zmianą wizerunku żołnierza rosyjskiego, dokonaną z wykorzystaniem już istniejących elementów składowych stereotypowego wizerunku i poszerzeniem go o dodatkowe pozytywne składniki. 


\section{Źródła}

\section{Bibliografia}

Daszyński I. (1957). Pamiętniki t. 2. Warszawa: Książka i Wiedza.

Gajewska J. (2014), Ta wojna zmieni wszystko. Dziennik Janiny Gajewskiej. Warszawa: Naczelna Dyrekcja Archiwum Państwowych.

Glinka W. (1927), Pamiętnik z wielkiej wojny T.1: Narew - Berezyna. Warszawa: Skład Główny Gebethner i Wolff.

Hołówko T. (1924), Ze wspomnień germanofila. Materiaty z dziejów walk o niepodlegtość, t. 1. Warszawa.

Jankowski Cz. (1923), Z dnia na dzień. Warszawa 1914 - 1915 Wilno. Wilno: Wydawnictwo Kazimierza Rutskiego.

Lednicki A. (1994), Pamiętnik 1914 - 1918. Warszawa: Biblioteka Narodowa.

Lubomirska M. (2002), Pamiętnik księżnej Marii Zdzistawowej Lubomirskiej. 1914-1918. Poznań: Wydawnictwo Poznańskie.

Ostrowska L. (2014), Trochę zazdrości się tym, co nie dożyli tych czasów. Dziennik Ludwiki Ostrowskiej z Maluszyna. Warszawa: Naczelna Dyrekcja Archiwów Państwowych.

Pamiętniki chtopów, (1935). Warszawa: Instytut Gospodarstwa Społecznego.

Pamiętniki chtopów serja druga, (1936). Warszawa: Instytut Gospodarstwa Społecznego.

Szuścik J. (1925), Pamiętnik z wojny i niewoli. Cieszyn: Drukarnia P. Mitręgi.

\section{Monografie i publikacje zbiorowe}

Achmatowicz A. (2003), Polityka Rosji w kwestii polskiej w pierwszym roku Wielkiej Wojny 191-1915. Warszawa: Neriton. Chwalba A. (2014), Samobójstwo Europy. Kraków: Wydawnictwo Literackie.

Dobroński A.Cz. (1976), Dyslokacja wojsk rosyjskich w Królestwie Polskim przed I Wojną Światową. Studia i materiały do historii wojskowości, t. 20. Białystok, s. 241-284.

Dobroński A.Cz. (1979), Pobór do armii rosyjskiej i stużba w niej żotnierzy z Królestwa Polskiego (1907-1914). Studia i materiały do historii wojskowości, t. 22. Białystok, s. 243-275.

Florczak I. (2018), Obraz armii rosyjskiej w okupowanej Galicji w świetle dzienników i $\quad$ wspomnień (1914-1915). Acta Universitatis Lodziensis Folia Historica, 102, Łódź: Wydawnictwo Uniwersytetu Łódzkiego, s. $75-87$.

Jaroniec P. (2016), Obraz żotnierzy Armii Czerwonej we wspomnieniach kombatantów „ludowego” Wojska Polskiego walczącego na froncie wschodnim w latach 1943- $\quad$ 1945, publikowanych w polskiej prasie codziennej w latach 70. XX w. Przyczynek do zagadnienia. Studia z dziejów wojskowości, t. 5. Białystok, s. 193-214.

Legieć J. (2013), Stużba rekrutów z Królestwa Polskiego w armii rosyjskiej w latach 1874-1913. Kielce: Wydawnictwo Uniwersytetu Jana Kochanowskiego.

Przeniosło M. (1999), Chtopi Królestwa Polskiego wobec Legionów Polskich 1914-1916 [w:] S. Kalębka, N. Kasperek (red.), Między irredenta a kolaboracją. Postawy spoteczeństwa polskiego wobec zaborców. Olsztyn: Wydawnictwo Uniwersytetu Warmińsko-Mazurskiego, s. 167-180.

Smoliński A. (2017), Wizerunek piechura, kawalerzysty i Kozaka Armii Rosyjskiej oraz jeńca rosyjskiego z czasów Wielkiej Wojny w dziennikach, pamiętnikach i wspomnieniach żołnierzy Legionów Polskich [w:] A. Smoliński (red.), Mato znana I wojna światowa. Studia i szkice z dziejów Wielkiej Wojny na froncie wschodnim. Grajewo: Stara Szuflada, s. 95-175.

\section{Prasa}

„Kurier Warszawski” (1914), nr 209, s. 4.

„Kurier Warszawski” (1914), nr 211 dodatek nadzwyczajny.

„Kurier Warszawski” (1914), nr 211 2-gi dodatek nadzwyczajny.

\section{Słowniki}

Głowiński M. (1976) [w:] J. Sławiński (red.), Stownik terminów literackich, (wyd. 1, s. 289). Wrocław: Zakład Narodowy im. Ossolińskich. 